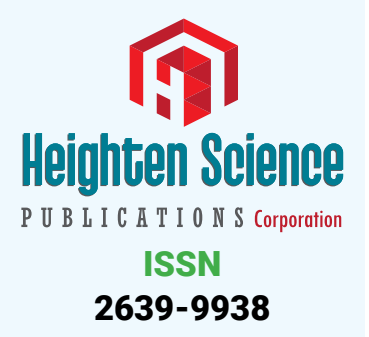

*Address for Correspondence: Razvodovsky YE, 80 Gorky Street, Grodno 230009, Belarus, Tel: +375 01527018 84; Fax: +375 01524353 41, Email: razvodovsky@tut.by; yury_razvodovsky@mail.ru

Submitted: 15 December 2017

Approved: 28 December 2017

Published: 29 December 2017

Copyright: @ 2017 Razvodovsky YE. This is an open access article distributed under the Creative Commons Attribution License which permits unrestricted use, distribution, and reproduction in any medium, provided the original work is properly cited

Keywords: Affordability; Tax; Price; Vodka; Sales; Russia; 2010-2015

Check for updates
Short Communication

\section{The effects of alcohol taxation and pricing policies on vodka sales in Russia}

\author{
Razvodovsky YE* \\ International Academy of Sobriety, Belarus
}

\section{Abstract}

Background: The majority of aggregate econometric studies indicate that higher taxes and real prices on alcohol significantly reduce the alcohol consumption.

Objectives: To estimate the effects of recent alcohol taxation and pricing policies on vodka sales per capita in Russia.

Methods: Trends in the affordability of vodka, excise tax rates on vodka, real and minimum price of vodka and per capita vodka sales between 2010 and 2015, were compared.

Results: A Pearson's correlation analysis suggests a positive and statistically significant association between the affordability of vodka and per capita vodka sales. The association between vodka sales and excise tax rates on vodka, the real price of vodka and minimum price of vodka was negative. Russia.

Conclusions: These findings indicate that pricing policy has potential to reduce binge drinking of vodka in

\section{Background}

Harmful drinking was identified as one of the major contributor to premature death toll in Russia [1,2]. Recent estimates suggest that alcohol may be responsible for $59 \%$ of all deaths of working-age men [3]. The high level of alcohol-related mortality in Russia seems to have been underpinned by high overall level of alcohol consumption and binge drinking pattern [4]. The current alcohol consumption figure in Russia is one of the highest in the world (16.6 liters of pure alcohol in 2005) [5].

Through the centuries the scale of alcohol-related problems was underestimated by the Russian government [6]. Recently the government has become increasingly concerned about the public's health, as it has realized that population decline is a serious threat to the long-term development of the economy [7]. Anti-alcohol activity in Russia began with the adoption of two laws in 2005, which increased government control over the alcohol market [8].

An active phase of the alcohol reform was started in 2009, when the Federal Service for Alcohol Market Regulation (Rosalkogolregulirovanie) was established. In January 2010, the minimum price on vodka was introduced. Most importantly, excise tax rates on vodka in Russia have been increased [9]. Further, a new set of amendments to the 171 Federal Low were adopted in 2011 [8]. A wide range of new regulations was imposed on the manufacture and sale of alcoholic beverages in 2012 [10]. There are some indications, that mortality has been improving in Russia in the past decade, due in part to the government's measures that have made alcohol less affordable [11,12].

Available evidence suggests that low price is one of the major drivers of alcohol consumption and alcohol-related harm $[13,14]$. The majority of aggregate econometric 
studies indicate that higher taxes and real prices on alcohol significantly reduce the alcohol consumption [13-16]. It was suggested that reducing the affordability of alcohol is one of the most effective interventions for reducing the harm caused by alcohol [17]. Russian historical perspective also provides evidence that decreasing in vodka affordability by rising taxes is the effective strategy for reducing alcohol-related harm [6].

Against this background, it would be interesting to estimate the effects of recent alcohol taxation and pricing policies on vodka sales per capita in Russia. In relation to this, trends in the affordability of vodka, excise tax rates on vodka, real and minimum price of vodka and per capita vodka sales between 2010 and 2015, were compared.

\section{Methods}

The data on vodka sales (in liters per capita), excise tax rates on vodka, average salary and real retail and minimum price of vodka are taken from the Russian State Statistical Committee (Rosstat) reports (http://www.gks.ru/). Here we specified the number of liters of vodka that an average monthly salary could buy as the affordability of vodka. To examine the relation between dependent variable (vodka sales) and independent variables (excise tax rates on vodka, real retail and minimum price of vodka, affordability of vodka) a Pearson correlation analysis was performed using the statistical package "Statistica 12. StatSoft".

\section{Results}

The excise tax rates on vodka in Russia have increased 2.4 times (from 210 to 500 rubles per liter of pure alcohol) between 2010 and 2015 (Figure1). The real price of vodka has also increased 2.4 times (from 230 to 559 rubles per 0.5 liter) during this period. The minimum price of vodka has increased 2.1 times: the cost of the cheapest bottle (half a liter) of vodka grew from 89 rubles in 2010 to 185 rubles in 2015. As a result, the affordability of vodka has decreased significantly (by 38.3\%) between 2010 and 2015: the average salary in 2010 could buy 91.0 liters of vodka compared with 60.9 liters in 2015. During the same period per capita vodka sales has decreased by $38.3 \%$ (from 4.7 to 2.9 liters).

A Pearson's correlation analysis suggests a positive and statistically significant association between the affordability of vodka and vodka sales per capita ( $r=0.96$; $\mathrm{p}<0.000)$. The association between vodka sales and excise tax rates on vodka $(\mathrm{r}=-0.95$; $\mathrm{p}<0.000)$, the real price of vodka $(\mathrm{r}=-0.97 ; \mathrm{p}<0.000)$ and minimum price of vodka $(\mathrm{r}=-$ $0.88 ; \mathrm{p}<0.000$ ) was negative.

\section{Discussion}

The results of the analysis suggest an inverse relationship between excise tax rates on vodka, real and minimum price of vodka and sales of vodka at the aggregate

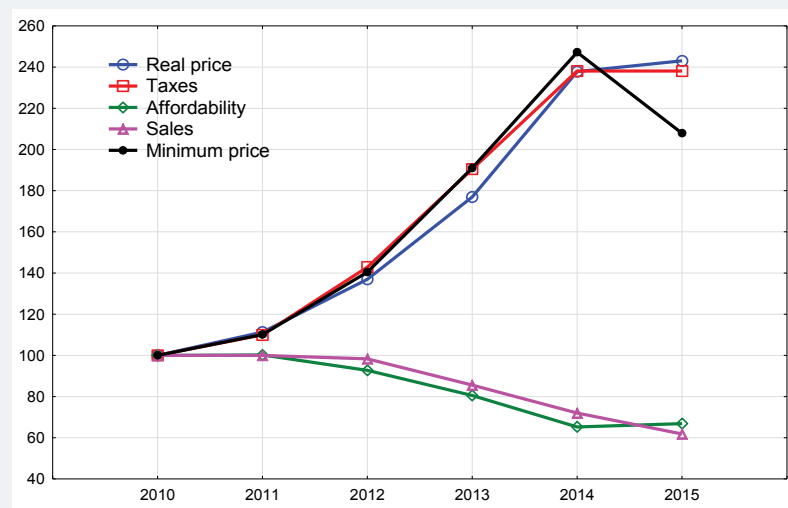

Figure 1: Indices of real and minimum price, tax, affordability and per capita vodka sales in Russia (2010-100\%) 
level. These findings are consistent with the principle that increasing the price of alcohol reduces its consumption [13-16]. A significant decreasing in the affordability of vodka appears to have been a major driver of dramatic decreasing in vodka sales between 2010 and 2015. It is clear that this development might be attributed to the implementation of the alcohol policy measures over the last years. The policies included strict regulations on alcohol products, which resulted in a decline of distributors and increased consumer prices [7]. Making vodka less affordable through differential taxation was an essential element of the Russian alcohol policy. Unfortunately, facing economic crisis the Russian government reduced minimum price on vodka by $16 \%$ from February 1, 2015, which means the increasing in the affordability of vodka [18].

Before concluding, some potential limitations of this study must be addressed. First and foremost: the use of simple correlation in the analysis of time series may lead to false correlations, which can be avoided by using the method of ARIMA (autoregressive integrated moving average), which requires around 50 time points [19]. Further, we relied on official vodka sales data across the study period. However, statistics on recorded alcohol consumption in Russia suffer from a high degree of uncertainty, especially in the post-Soviet period [5]. Finally, the unrecorded consumption of alcohol was commonplace in Russia throughout the study period, especially in the most recent years, when a considerable proportion of vodka came from illicit sources [18].

Overall, the results from this study suggest that in Russia, consumer demand for vodka is very responsive to price. These findings indicate that pricing policy has potential to reduce binge drinking of vodka in Russia. Russian government should consider the complementary effects of other alcohol policies that could be implemented concurrently to reduce alcohol-related burden. It is necessary to address several issues: high level of alcohol consumption among working-age men, high availability of alcohol for young adults and consumption of illegal alcohol and non-beverage alcohol surrogates. Alcohol control policy should be based on the scientific evidence and be sensitive to national context. The main goal of alcohol control policy must be the substantial decrease of alcohol consumption per capita.

\section{References}

1. Nemtsov AV, Razvodovsky YE. Alcohol situation in Russia: 1980-2005. Journal Clinical Psychiatry. 2008; 2: 52-60. Ref.: https://goo.gl/n6zukR

2. Moskalewicz J, Razvodovsky YE, Wieczorek L. East-west disparities in alcohol-related harm Alcoholism and Drug Addiction. 2016; 29: 209-222. Ref.: https://goo.gl/uLvvur

3. Zaridze D, Lewington S, Boroda A, Scélo G, Karpov R, et al. Alcohol and mortality in Russia: prospective observational study of 151,000 adults. Lancet. 2014; 383: 1465-1473. Ref.: https://goo.gl/aFi68T

4. Stickley $A$, Leinsalu M, Andreew E, Razvodovsky YE, Vagero D, et al. Alcohol poisoning in Russia and the countries in the European part of the former Soviet Union, 1970 2002. Eur J Public Health. 2007; 17: 444-449. Ref.: https://goo.gl/anVuq5

5. Nemtsov AV, Razvodovsky YE. The estimation of the level of alcohol consumption in Russia: a review of the literature. Sobriology. 2017; 1:78-88.

6. Stickley A, Razvodovsky Y, McKee M. Alcohol mortality in Russia: A historical perspective. Public Health. 2009; 123: 20-26. Ref.: https://goo.gl/JzABM9

7. Nemtsov AV, Razvodovsky YE. Russian alcohol policy in false mirror. Alcohol Alcohol. 2016; 51: 626627. Ref.: https://goo.gl/TZ9Hn3

8. Khalturina D, Korotaev A. Effects of specific alcohol control policy measures on alcoholrelated mortality in Russia from 1998 to 2013. Alcohol Alcohol. 2015; 50: 588-601. Ref.: https://goo.gl/J3axrE

9. Gil A, Khaltourina D, Korotaev A. Alcohol consumption in Russia: affordability of alcohol, changes and effects of alcohol control policy and future prospects. In: Changes in alcohol affordability and availability. Twenty years of transition in Eastern Europe. Eds Moskalewicz $\mathrm{J}$ and Osterberg $\mathrm{E}$ Juvenes Print. 2016; 18-50. Ref.: https://goo.gl/RqLBg9 
10. Radaev V. Impact of a new alcohol policy on homemade alcohol consumption and sales in Russia. Alcohol Alcohol. 2015; 50: 365-72. Ref.: https://goo.gl/j3qugj

11. Razvodovsky YE. Was the mortality decline in Russia attributable to alcohol control policy? Journal of Sociolomics. 2014; 3: 2.

12. Razvodovsky YE, Nemtsov AV. Alcohol-related component of the mortality decline in Russia after 2003. The Questions of Narcology. 2016; 3: 63-70.

13. Chaloupka FJ, Grossman M, Saffer H. The effects of price on alcohol consumption and alcoholrelated problems. Alcohol Res Health. 2002; 26: 22-34. Ref.: https://goo.gl/yKMzSY

14. Moskalewicz J, Osterberrg E, Razvodovsky YE. Summary. In: Changes in alcohol affordability and availability. Twenty years of transition in Eastern Europe. Eds Moskalewicz $\mathrm{J}$ and Osterberg $\mathrm{E}$ Juvenes Print. 2016; 157-168. Ref.: https://goo.gl/ESBG9G

15. Razvodovsky YE. Affordability of alcohol and alcohol-related mortality in Belarus. Adicciones. 2013; 25: 156-162. Ref.: https://goo.gl/Pj7vUi

16. Razvodovsky YE. Alcohol affordability and epidemiology of alcoholism in Belarus. Alcoholism. 49: 29-35.

17. Wagenaar AC, Tobler AL, Komro KA. Effects of alcohol tax and price policies on morbidity and mortality: A systematic review. Am J Pub Health. 2010; 100: 2270-2278. Ref.: https://goo.gl/H8xTAV

18. Razvodovsky YE. Comments on "Some aspects of nonbeverage alcohol consumption in the former Soviet Union". Psychiatry Journal. 2013; 1: 1-2.

19. Norström T. The use of aggregate data in alcohol epidemiology. British Journal of Addiction. 1989; 84: 969-977. Ref.: https://goo.gl/RmfJc3 